\title{
Antibiotic susceptibility profiles of Mycoplasma bovis strains isolated from cattle in Hungary, Central Europe
}

\author{
Kinga M Sulyok', Zsuzsa Kreizinger ', Lilla Fekete', Veronika Hrivnák', Tibor Magyar', Szilárd Jánosi², \\ Nóra Schweitzer ${ }^{2}$, Ibolya Turcsányi ${ }^{2}$, László Makrai ${ }^{3}$, Károly Erdélyi ${ }^{2}$ and Miklós Gyuranecz ${ }^{1 *}$
}

\begin{abstract}
Background: Mycoplasma bovis is a worldwide pathogen, causative agent of pneumonia, mastitis, arthritis, and a variety of other symptoms in cattle. The economic losses due to mycoplasma pneumonia could be reduced by antibiotic treatment. The aim of the present study was to determine the in vitro susceptibility of $M$. bovis strains isolated from cattle in Hungary to eleven antibiotics.

Results: Minimal inhibitory concentration (MIC) values of $35 \mathrm{M}$. bovis strains collected from different parts of Hungary between 2010 and 2013 were determined by the microbroth dilution method. Strains with high MIC values were found in the case of all applied antibiotics. The most effective antibiotics tested in vitro were fluoroquinolones ( $\mathrm{MIC}_{90}$ danofloxacin $0.312 \mu \mathrm{g} / \mathrm{ml}$, enrofloxacin $0.312 \mu \mathrm{g} / \mathrm{ml}$, marbofloxacin $\left.0.625 \mu \mathrm{g} / \mathrm{ml}\right)$. Our results confirm the observations of increasing MIC values to antibiotics commonly used in the therapy of mycoplasma infections, primarily to tetracyclines; tetracycline $\left(\mathrm{MIC}_{90} 16 \mu \mathrm{g} / \mathrm{ml}\right)$ and oxytetracycline $\left(\mathrm{MIC}_{90} \geq 64 \mu \mathrm{g} / \mathrm{ml}\right)$ and macrolides; tylosin $\left(\mathrm{MIC}_{90} \geq 128 \mu \mathrm{g} / \mathrm{ml}\right.$ ) and tilmicosin $\left(\mathrm{MIC}_{90} \geq 128 \mu \mathrm{g} / \mathrm{ml}\right)$. The growth of many $\mathrm{M}$. bovis strains was not inhibited by gentamicin $\left(\mathrm{MIC}_{90} 8 \mu \mathrm{g} / \mathrm{ml}\right.$ ), spectinomycin $\left(\mathrm{MIC}_{90} \geq 256 \mu \mathrm{g} / \mathrm{ml}\right)$, florfenicol $(\mathrm{MIC} 90 \mathrm{mg} / \mathrm{ml}$ ) or lincomycin $\left(M^{\prime} C_{90} \geq 64 \mu \mathrm{g} / \mathrm{ml}\right)$.

Conclusions: Our results emphasize the necessity of periodic testing for antibiotic susceptibility in this geographic region. Based on our in vitro examinations, fluoroquinolones could be the most effective drugs for the therapy of M. bovis infections in Hungary. However, current antimicrobial use policies have to be taken into account to avoid further antibiotic resistance development and to reserve fluoroquinolones for the treatment of severe infections which have responded poorly to other classes of antimicrobials.
\end{abstract}

Keywords: Antibiotic resistance, MIC, Fluoroquinolones, Microbroth dilution, Mycoplasma bovis

\section{Background}

Mycoplasma bovis is a widely distributed pathogen, first isolated in the USA in 1961 from a case of severe mastitis in cattle [1]. It is associated with various diseases in cattle including calf pneumonia, mastitis, arthritis, otitis media and genital disorders [2]. M. bovis is considered responsible for a quarter to a third of economic losses in the cattle industry caused by respiratory diseases [3].

\footnotetext{
* Correspondence: m.gyuranecz@gmail.com

${ }^{1}$ Institute for Veterinary Medical Research, Centre for Agricultural Research, Hungarian Academy of Sciences, Hungária körút 21, Budapest 1143, Hungary Full list of author information is available at the end of the article
}

In Hungary, the average seropositivity rate of individual animals was found to be $11.3 \%$, in certain herds it even exceeded $50.0 \%$. Tested by enzyme-linked immunosorbent assay the overall rate of seropositive herds was $64.7 \%$ [4]. With the exception of seroprevalence on individual level, these values are relatively high in a European context $[3,5]$.

Since no effective vaccine is available against $M$. bovis, adequate housing and appropriate antibiotic treatment are promoted in the control of the diseases caused by this agent. Antibiotic therapy of mastitis has often failed, but antimicrobial treatment of pneumonia has shown some success and it may help reduce economic losses $[3,6]$. Mycoplasmas are intrinsically resistant to $\beta$-lactam

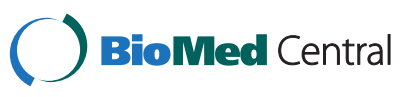

(c) 2014 Sulyok et al.; licensee BioMed Central Ltd. This is an Open Access article distributed under the terms of the Creative Commons Attribution License (http://creativecommons.org/licenses/by/4.0), which permits unrestricted use, distribution, and reproduction in any medium, provided the original work is properly credited. The Creative Commons Public Domain Dedication waiver (http://creativecommons.org/publicdomain/zero/1.0/) applies to the data made available in this article, unless otherwise stated. 
antimicrobials and sulphonamides, because they do not possess a cell wall and do not synthesize folic acid. Mycoplasmas are generally susceptible to antibiotics that affect protein (tetracyclines, macrolides, lincosamides, phenicols) or nucleic acid synthesis (fluoroquinolones) [2]. The decreased effectiveness of certain antimicrobial agents (spectinomycin, oxytetracycline and tilmicosin) traditionally used in the therapy of mycoplasma infections was reported in Europe [7].

The aim of this study was to determine the susceptibility of 35 Hungarian $M$. bovis isolates to eleven antibiotics using the microbroth dilution method.

\section{Methods}

Thirty-five $M$. bovis strains originating from dairy herds located in different parts of Hungary were tested in this study (Table 1, Figure 1). The samples were collected during routine diagnostic examinations or necropsies between 2010 and 2013. Ethical approval was not required for the study as all samples were collected during routine diagnostic examinations or necropsies. Nasal swabs, lung samples and a single lymph node were homogenized in $2 \mathrm{ml}$ of Mycoplasma broth medium ( $\mathrm{pH}$ 7.8) (Thermo Fisher Scientific Inc./Oxoid Inc./, Waltham, MA) supplemented with $0.5 \%(\mathrm{w} / \mathrm{v})$ sodium pyruvate, $0.5 \%(\mathrm{w} / \mathrm{v})$ glucose and $0.005 \%(\mathrm{w} / \mathrm{v})$ phenol red and cultured at $37^{\circ} \mathrm{C}$ in a $5 \% \mathrm{CO}_{2}$ atmosphere. Following colour change (red to yellow shift) the cultures were inoculated onto solid Mycoplasma media (Thermo Fisher Scientific Inc. /Oxoid Inc./) and were incubated at $37^{\circ} \mathrm{C}$ and $5 \% \mathrm{CO}_{2}$ for 3 days, until visible colonies appeared. Mixed cultures were filter cloned only once to exclude contaminant Mycoplasma species and to minimize in vitro mutations of the isolates. DNA extraction was performed using the QIAamp DNA Mini Kit (Qiagen Inc., Hilden, Germany) according to the manufacturers' instructions for Gram-negative bacteria. All isolates were identified by polymerase chain reaction (PCR) targeting the $u v r C$ gene of M. bovis [8]. The purity of the cultures (e.g. to exclude M. arginini or other Mycoplasma spp. contamination) was confirmed by a universal Mycoplasma PCR system targeting the 16S/23S rRNA intergenic spacer region in Mollicutes [9] followed by sequencing on an ABI Prism 3100 automated DNA sequencer (Applied Biosystems, Foster City, CA), sequence analysis and BLAST search. The same once filter cloned passage of each $M$. bovis strain was submitted for a 4 gene based multi-locus sequence typing (MLST) and the sequencing data confirmed the purity of the isolates at strain level (i.e. not more than one $M$. bovis strain in the culture) [10]. Mixed primary cultures which failed to be purified by a single filter cloning were excluded from the study (data not shown). Aliquots of the third passage of purified cultures were stored frozen at $-70^{\circ} \mathrm{C}$ until required. The number of colour changing units (CCU) was calculated by microplate dilution method, from the lowest dilution showing colour change after one week of incubation [11,12].

The following antimicrobial agents were examined during the microbroth dilution tests: three fluoroquinolones: danofloxacin (batch SZBA019XV), enrofloxacin (batch SZBA336XV) and marbofloxacin (batch SZBC248XV); two aminoglycosides: gentamicin (batch 051K17475V) and spectinomycin (batch SZBB166XV); two tetracyclines: oxytetracycline (batch SZBC320XV) and tetracycline (batch SZBA140XV); two macrolides: tilmicosin (batch SZBC345XV) and tylosin (batch SZBB160XV); one phenicol: florfenicol (batch SZBC223XV) and one lincosamide: lincomycin (batch SZBC340XV); all products originated from VETRANAL, Sigma-Aldrich, Germany. They were diluted and stored according to the recommendations of Hannan [11]. Stock solutions of $1 \mathrm{mg} / \mathrm{ml}$ enrofloxacin, danofloxacin and marbofloxacin were prepared in $0.1 \mathrm{M} \mathrm{NaOH}$; stock solution of $1 \mathrm{mg} / \mathrm{ml}$ florfenicol was prepared in $96 \%$ ethanol and in sterile distilled water; and the rest of the stock solutions of $1 \mathrm{mg} / \mathrm{ml}$ were prepared in sterile distilled water. All aliquots were stored at $-70^{\circ} \mathrm{C}$ until needed, and dilutions were freshly prepared for each microtest. Twofold dilutions were prepared in the range $0.039-10 \mu \mathrm{g} / \mathrm{ml}$ for fluoroquinolones, $0.125-32 \mu \mathrm{g} / \mathrm{ml}$ for florfenicol, $0.25-64 \mu \mathrm{g} / \mathrm{ml}$ for gentamicin, tetracyclines and lincomycin, $0.5-128 \mu \mathrm{g} / \mathrm{ml}$ for macrolides and 1-256 $\mu \mathrm{g} / \mathrm{ml}$ for spectinomycin.

The microbroth dilution test was performed as recommended by Hannan [11] using $10^{4}-10^{5} \mathrm{CCU} / \mathrm{ml}$ of each strain. In brief, the 96-wells microtiter plates were designed to contain growth control (broth medium without antibiotic), sterility control (broth medium without antibiotic and Mycoplasma inoculum) and $\mathrm{pH}$ control (broth medium adjusted to $\mathrm{pH}$ 6.8) wells. Mycoplasma broth medium (pH 7.8) (Thermo Fisher Scientific Inc./Oxoid Inc./) supplemented with $0.5 \%(\mathrm{w} / \mathrm{v})$ sodium pyruvate, $0.5 \%(\mathrm{w} / \mathrm{v})$ glucose and $0.005 \%(\mathrm{w} / \mathrm{v})$ phenol red was used as a culture medium. The duplicates of three clinical isolates and the duplicate of the type strain (M. bovis PG45, NCTC 10131) were tested on each 96-well microtiter plates.

The MIC (minimal inhibitory concentration) value of each isolate was defined as the lowest concentration of the antibiotic that completely inhibits the growth in the broth (no pH and colour change) after a one week incubation period [12]. $\mathrm{MIC}_{50}$ and $\mathrm{MIC}_{90}$ values were defined as the lowest concentrations that inhibit 50\% and $90 \%$ of bacterial isolates. The type strain (M. bovis PG45, NCTC 10131) was used for the quality control of MIC determination (Table 1).

\section{Results}

Our MIC values of $M$. bovis type strain PG45 were identical with values previously obtained for danofloxacin, enrofloxacin, marbofloxacin, spectinomycin, tilmicosin 
Table 1 Background information and MIC data of the 35 Hungarian $M$. bovis isolates included in this study

\begin{tabular}{|c|c|c|c|c|c|c|c|c|c|c|c|c|c|c|}
\hline \multirow{3}{*}{$\begin{array}{l}\text { Sample } \\
\text { ID }\end{array}$} & \multirow{3}{*}{$\begin{array}{l}\text { Origin } \\
\text { of herd }\end{array}$} & \multirow[t]{3}{*}{ Date } & \multirow{3}{*}{$\begin{array}{l}\text { Sample } \\
\text { source }\end{array}$} & \multicolumn{11}{|c|}{ MIC values $(\mu \mathrm{g} / \mathrm{ml})$} \\
\hline & & & & \multicolumn{3}{|c|}{ Fluoroquinolones } & \multicolumn{2}{|c|}{ Aminoglycosides } & \multicolumn{2}{|l|}{ Tetracyclines } & \multicolumn{2}{|l|}{ Macrolides } & \multirow{2}{*}{$\begin{array}{l}\text { Phenicol } \\
\text { Florfenicol }\end{array}$} & \multirow{2}{*}{$\begin{array}{l}\text { Lincosamide } \\
\text { Lincomycin }\end{array}$} \\
\hline & & & & Danofloxacin & Enrofloxacin & Marbofloxacin & Gentamicin & Spectinomycin & Oxytetracycline & Tetracycline & Tilmicosin & Tylosn & & \\
\hline PG45 & Connecticut & 1961 & Lung & 0.156 & 0.156 & 0.625 & 4 & 4 & 2 & 0.25 & 0.5 & 0.5 & 4 & 1 \\
\hline MYC2 & Püspökhatvan & 2011 & Lung & 0.156 & 0.156 & 0.625 & 2 & 2 & 16 & 4 & 128 & 16 & 4 & 1 \\
\hline MYC22 & Sümeg & 2012 & Lung & 0.156 & 0.312 & 0.625 & 4 & 256 & 64 & 16 & 128 & 128 & 8 & 64 \\
\hline MYC30 & Bugyi & 2012 & Lung & 0.156 & 0.156 & 0.625 & 4 & 256 & 32 & 8 & 128 & 128 & 4 & 64 \\
\hline MYC42 & Nemti & 2012 & Lung & 0.156 & 0.156 & 0.625 & 8 & 4 & 64 & 8 & 128 & 32 & 8 & 1 \\
\hline MYC43 & Zsana & 2012 & Lung & 0.156 & 0.156 & 0.312 & 4 & 256 & 64 & 16 & 128 & 128 & 8 & 64 \\
\hline MYC44 & Győrszentiván & 2012 & Lung & 10 & 10 & 10 & 2 & 256 & 64 & 8 & 128 & 128 & 8 & 64 \\
\hline MYC45 & Budapest & 2012 & Lung & 10 & 10 & 10 & 2 & 256 & 64 & 8 & 128 & 128 & 4 & 64 \\
\hline MYC46 & Budapest & 2012 & Lung & 10 & 10 & 10 & 4 & 256 & 64 & 8 & 128 & 128 & 8 & 64 \\
\hline MYC47 & Dabas & 2012 & Lung & 0.156 & 0.156 & 0.625 & 8 & 256 & 64 & 8 & 128 & 128 & 8 & 64 \\
\hline MYC48 & Ősi & 2012 & $\begin{array}{l}\text { Nasal } \\
\text { swab }\end{array}$ & 0.156 & 0.156 & 0.625 & 8 & 256 & 64 & 16 & 128 & 128 & 4 & 64 \\
\hline MYC49 & Ősi & 2012 & $\begin{array}{l}\text { Nasal } \\
\text { swab }\end{array}$ & 0.156 & 0.156 & 0.625 & 8 & 256 & 64 & 16 & 128 & 128 & 4 & 64 \\
\hline MYC50 & Ősi & 2012 & Lung & 0.156 & 0.156 & 0.625 & 4 & 256 & 64 & 8 & 128 & 128 & 4 & 64 \\
\hline MYC51 & Ősi & 2012 & $\begin{array}{l}\text { Nasal } \\
\text { swab }\end{array}$ & 0.156 & 0.08 & 0.312 & 4 & 256 & 64 & 8 & 128 & 128 & 4 & 64 \\
\hline MYC52 & Solt & 2012 & Lung & 0.156 & 0.156 & 0.312 & 8 & 4 & 2 & 0.25 & 0.5 & 0.5 & 4 & 0.5 \\
\hline MYC53 & Solt & 2012 & Lung & 0.156 & 0.156 & 0.625 & 16 & 4 & 2 & 0.25 & 0.5 & 0.5 & 4 & 1 \\
\hline MYC65 & Csengersima & 2012 & $\begin{array}{l}\text { Nasal } \\
\text { swab }\end{array}$ & 0.156 & 0.156 & 0.625 & 2 & 2 & 64 & 16 & 128 & 8 & 4 & 0.5 \\
\hline MYC66 & Csengersima & 2012 & $\begin{array}{l}\text { Nasal } \\
\text { swab }\end{array}$ & 0.156 & 0.156 & 0.625 & 8 & 4 & 64 & 8 & 128 & 16 & 8 & 1 \\
\hline MYC67 & Csengersima & 2012 & Lung & 0.08 & 0.08 & 0.312 & 4 & 4 & 16 & 4 & 128 & 16 & 8 & 2 \\
\hline MYC68 & Csengersima & 2012 & Lung & 0.156 & 0.156 & 0.625 & 4 & 4 & 32 & 4 & 128 & 16 & 4 & 0.5 \\
\hline MYC69 & Komárom & 2013 & $\begin{array}{l}\text { Nasal } \\
\text { swab }\end{array}$ & 0.156 & 0.156 & 0.625 & 2 & 4 & 32 & 8 & 128 & 32 & 8 & 1 \\
\hline MYC70 & Komárom & 2013 & $\begin{array}{l}\text { Nasal } \\
\text { swab }\end{array}$ & 0.156 & 0.156 & 0.625 & 4 & 2 & 32 & 4 & 128 & 32 & 4 & 1 \\
\hline MYC71 & Komárom & 2013 & $\begin{array}{l}\text { Nasal } \\
\text { swab }\end{array}$ & 0.156 & 0.156 & 0.625 & 4 & 2 & 32 & 4 & 128 & 32 & 4 & 1 \\
\hline MYC72 & Komárom & 2013 & $\begin{array}{l}\text { Nasal } \\
\text { swab }\end{array}$ & 0.156 & 0.156 & 0.625 & 4 & 4 & 32 & 4 & 128 & 32 & 4 & 1 \\
\hline MYC73 & Komárom & 2013 & $\begin{array}{l}\text { Nasal } \\
\text { swab }\end{array}$ & 0.156 & 0.156 & 0.625 & 4 & 4 & 32 & 8 & 128 & 32 & 4 & 1 \\
\hline
\end{tabular}


Table 1 Background information and MIC data of the 35 Hungarian M. bovis isolates included in this study (Continued)

\begin{tabular}{|c|c|c|c|c|c|c|c|c|c|c|c|c|c|c|}
\hline MYC74 & Komárom & 2013 & $\begin{array}{l}\text { Nasal } \\
\text { swab }\end{array}$ & 0.156 & 0.156 & 0.625 & 4 & 4 & 32 & 8 & 128 & 16 & 4 & 1 \\
\hline MYC75 & Komárom & 2013 & $\begin{array}{l}\text { Nasal } \\
\text { swab }\end{array}$ & 0.156 & 0.08 & 0.312 & 2 & 2 & 32 & 4 & 128 & 32 & 4 & 1 \\
\hline MYC76 & Komárom & 2013 & $\begin{array}{l}\text { Nasal } \\
\text { swab }\end{array}$ & 0.156 & 0.156 & 0.625 & 4 & 4 & 64 & 8 & 128 & 16 & 8 & 2 \\
\hline MYC77 & Kertészsziget & 2010 & Lung & 0.312 & 0.156 & 0.625 & 2 & 256 & 64 & 8 & 128 & 128 & 4 & 64 \\
\hline MYC78 & Hosszúpályi & 2011 & Lung & 0.156 & 0.156 & 0.625 & 4 & 256 & 64 & 8 & 128 & 128 & 4 & 64 \\
\hline MYC79 & Hosszúpályi & 2011 & Lung & 0.156 & 0.156 & 0.625 & 8 & 256 & 64 & 16 & 128 & 128 & 8 & 64 \\
\hline MYC80 & Ebes & 2011 & $\begin{array}{l}\text { Lymph } \\
\text { node }\end{array}$ & 0.156 & 0.156 & 0.625 & 4 & 256 & 32 & 4 & 128 & 128 & 4 & 64 \\
\hline MYC81 & Felsőnyárád & 2013 & Lung & 0.156 & 0.156 & 0.625 & 8 & 256 & 64 & 8 & 128 & 128 & 4 & 64 \\
\hline MYC82 & Felsőnyárád & 2013 & $\begin{array}{l}\text { Nasal } \\
\text { swab }\end{array}$ & 0.156 & 0.156 & 0.625 & 4 & 256 & 64 & 8 & 128 & 128 & 8 & 64 \\
\hline MYC83 & Alsótold & 2013 & Lung & 0.312 & 0.156 & 0.625 & 4 & 256 & 64 & 8 & 128 & 128 & 8 & 64 \\
\hline MYC84 & Felsőnyárád & 2013 & $\begin{array}{l}\text { Nasal } \\
\text { swab }\end{array}$ & 0.156 & 0.156 & 0.625 & 4 & 256 & 64 & 8 & 128 & 128 & 4 & 64 \\
\hline
\end{tabular}




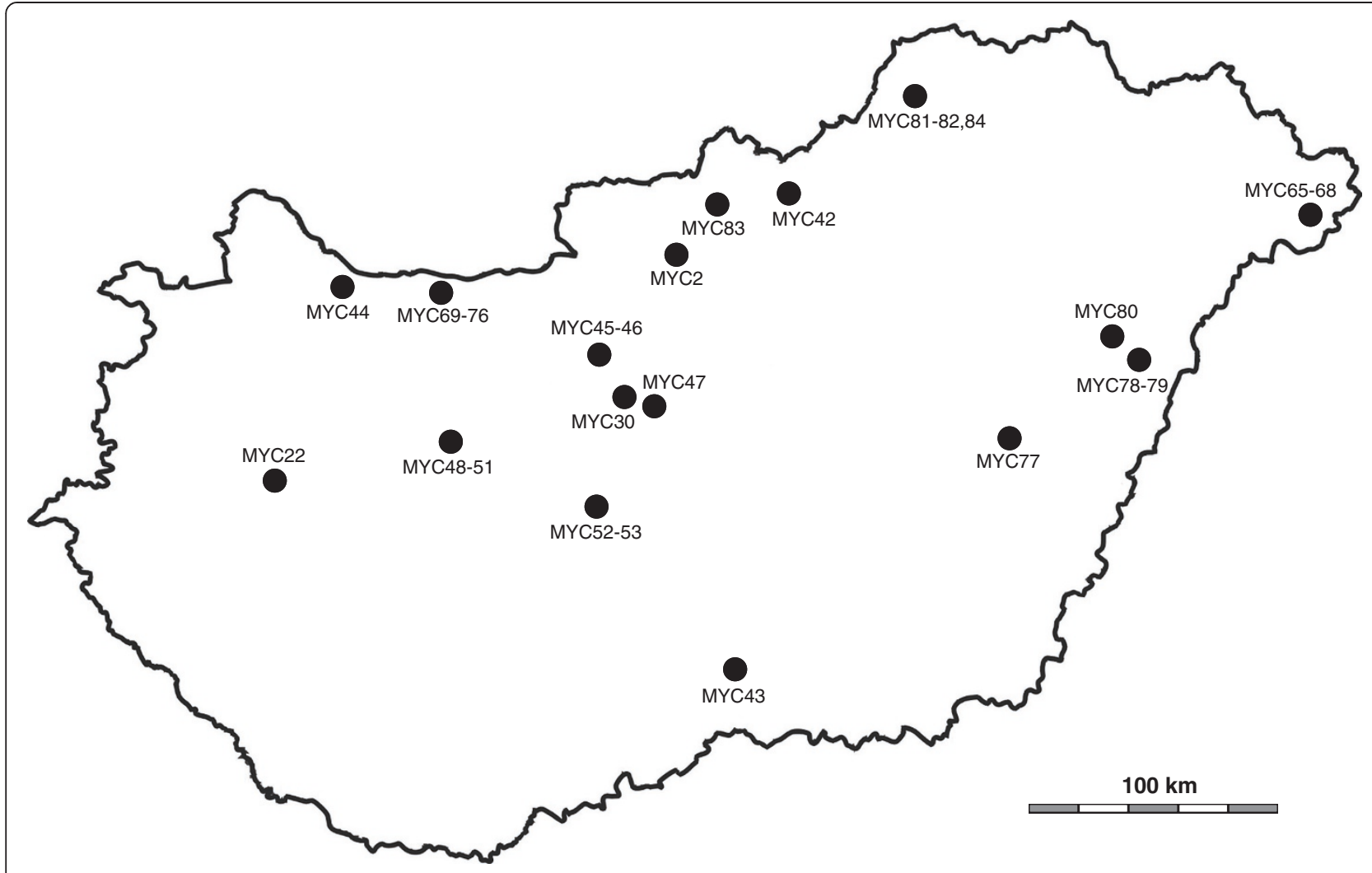

Figure 1 Map of Hungary showing the geographical origins of the $35 \mathrm{M}$. bovis isolates tested.

and tylosin using the microbroth dilution method Table 1; $[12,13]$. The MIC value of PG45 $(2 \mu \mathrm{g} / \mathrm{ml})$ for oxytetracycline was within the range of previously published studies applying microbroth dilution test $(0.1 / 0.125 / 0.16 / 4 \mu \mathrm{g} / \mathrm{ml})$ [6,11-13]. The MIC value $(1 \mu \mathrm{g} / \mathrm{ml})$ of PG45 for lincomycin was higher than in a previous study $(0.25 \mu \mathrm{g} / \mathrm{ml})$ [13]. For gentamicin, tetracycline, and florfenicol data determined by microbroth dilution test were not available. Our results for type strain PG45 were consistent throughout the study.

The MIC values of the eleven antimicrobial agents obtained from the examinations of the Hungarian M. bovis isolates are shown in Figure 2 and listed in Tables 1 and 2. Strains with elevated MIC values were found in the case of all applied antibiotics. Fluoroquinolones were found to be the most active compounds in vitro. The antibiotic susceptibility profiles of the Hungarian strains were consistent within the tested group of fluoroquinolones (Figure 2A-C). Three isolates (MYC44, MYC45 and MYC46) had high MIC values ( $\geq 10 \mu \mathrm{g} / \mathrm{ml})$ to danofloxacin, enrofloxacin and marbofloxacin, while the rest of the strains were inhibited by these antimicrobial agents with MICs $\leq 0.312$ or $0.625 \mu \mathrm{g} / \mathrm{ml}$. The MICs for gentamicin clustered steadily around the $\mathrm{MIC}_{50}$ value $(4 \mu \mathrm{g} / \mathrm{ml})$ (Figure 2D). MIC values of spectinomycin divided the strains into two distinct populations, with $48 \%$ of isolates yielding MICs of $\leq 4 \mu \mathrm{g} / \mathrm{ml}$ and the rest clustering with MICs $\geq 256 \mu \mathrm{g} / \mathrm{ml}$ (Figure 2E). Two $M$. bovis isolates (MYC52 and MYC53) originating from the same herd were inhibited by both tetracyclines and macrolides with low MIC values (Figure 2F-I). Among the macrolides, the MICs of tilmicosin showed bimodal distribution, as two strains yielded MICs $\leq 0.5 \mu \mathrm{g} / \mathrm{ml}$, while the rest yielded MICs $\geq 128 \mu \mathrm{g} / \mathrm{ml}$. The narrow range of MIC values $(4-8 \mu \mathrm{g} / \mathrm{ml})$ of florfenicol is demonstrated on Figure 2J. MICs for lincomycin also clustered the strains into a group with MICs $\leq 2 \mu \mathrm{g} / \mathrm{ml}$ and with MICs $\geq 64 \mu \mathrm{g} / \mathrm{ml}$ (Figure 2K).

Isolates originating from the same herd showed similar antibiotic susceptibility profiles (Table 1 ).

\section{Discussion}

Gerchman et al. [13] studied $11 \mathrm{M}$. bovis strains isolated from cattle imported from Hungary to Israel between 2005 and 2007. The most active compounds found during in vitro examinations were fluoroquinolones (danofloxacin, enrofloxacin and marbofloxacin), which is in accordance with our results, except that the MIC values described before were higher than the ones detected in this study ( $\mathrm{MIC}_{90} 1.25 \mu \mathrm{g} / \mathrm{ml}, 1.25 \mu \mathrm{g} / \mathrm{ml}, 5 \mu \mathrm{g} / \mathrm{ml}$ versus $0.312 \mu \mathrm{g} / \mathrm{ml}$, $0.312 \mu \mathrm{g} / \mathrm{ml}, 0.625 \mu \mathrm{g} / \mathrm{ml}$ ). Decreased spectinomycin susceptibility was detected in the strains from the imported 


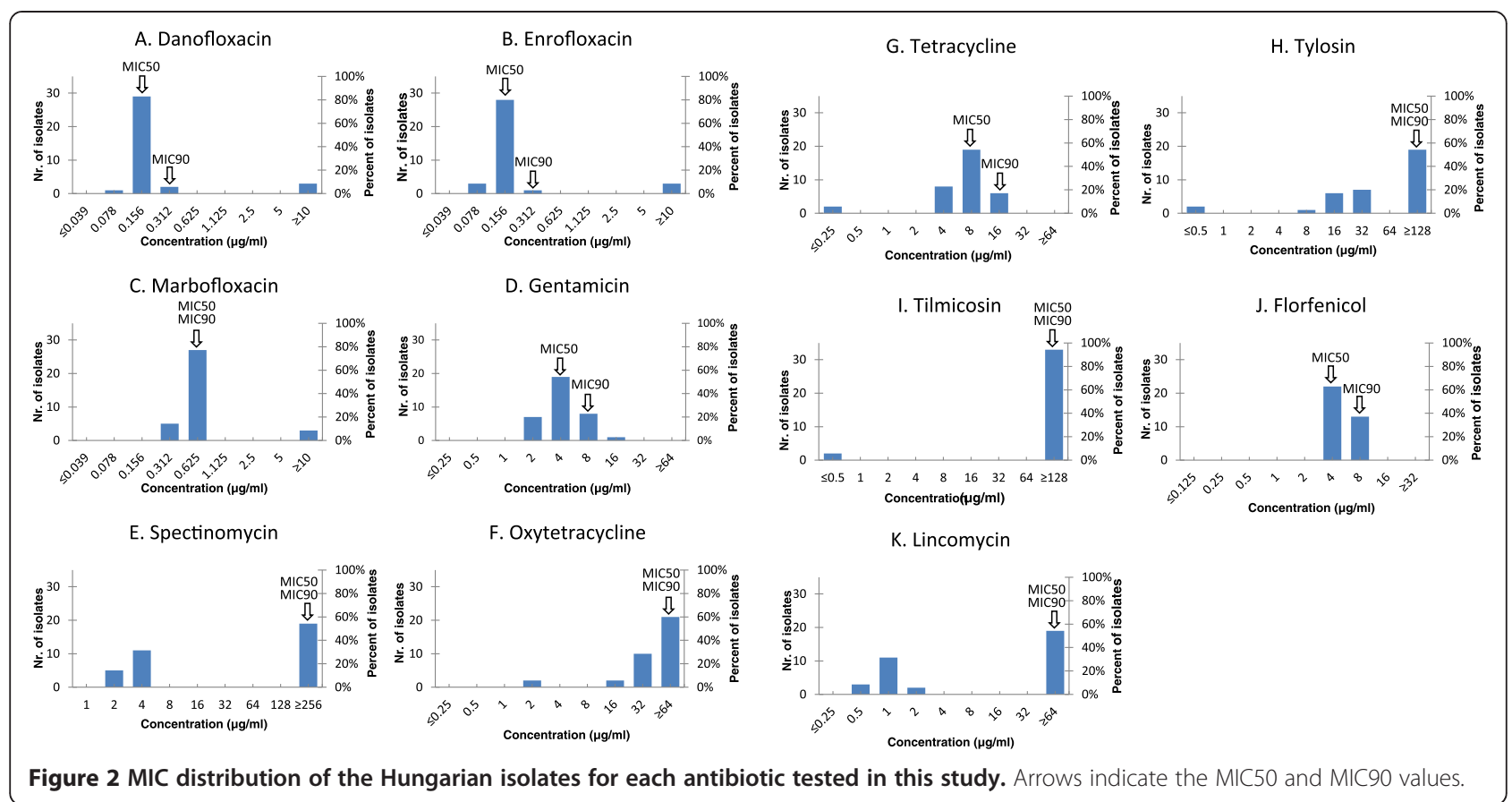

animals $\left(\mathrm{MIC}_{90}>1024 \mu \mathrm{g} / \mathrm{ml}\right.$ obtained with E-test method), which is consistent with our results ( $\left.\mathrm{MIC}_{90} \geq 256 \mu \mathrm{g} / \mathrm{ml}\right)$. In contrast to the results obtained by Gerchman et al. [13] $(4 \mu \mathrm{g} / \mathrm{ml}, 8 \mu \mathrm{g} / \mathrm{ml}, 1 \mu \mathrm{g} / \mathrm{ml})$ the $\mathrm{MIC}_{90}$ values of oxytetracycline $(\geq 64 \mu \mathrm{g} / \mathrm{ml})$, tilmicosin $(\geq 128 \mu \mathrm{g} / \mathrm{ml})$ and tylosin $(\geq 128 \mu \mathrm{g} / \mathrm{ml})$ yielded in the present study indicate limited susceptibility to these antibiotics. The comparison of the results of the previous publication and the present study emphasize the importance of the systematic monitoring of antibiotic susceptibility of $M$. bovis strains in the region $[13,14]$.

Fluoroquinolones inhibited the growth of the majority of the Hungarian M. bovis strains at low MIC values (with only 3 exceptions), confirming previous observations that this group of antimicrobial agents is effective against M. bovis [6,7,13-18]. MIC values of marbofloxacin were remarkably higher than that of danofloxacin and enrofloxacin. The observed difference, first noted by Gerchman et al. [13] is probably due to the increased use of marbofloxacin during the past years [13]. Extremely high MIC values for fluoroquinolones $(\geq 10 \mu \mathrm{g} / \mathrm{ml})$ were found in strains MYC44-46. The similarity in the resistance profile of these three strains is consistent with the results of a previous genetic study in the country, where these strains clustered into a separate subclade by MLST [10].

Most Hungarian $M$. bovis strains included in the present examination showed moderate susceptibility to gentamicin, with similar or lower $\mathrm{MIC}$ values $\left(\mathrm{MIC}_{90} 8 \mu \mathrm{g} / \mathrm{ml}\right)$

Table 2 Summary of range, mode, $\mathrm{MIC}_{50}$ and $\mathrm{MIC}_{90}$ values of the $35 \mathrm{M}$. bovis strains isolated from cattle in Hungary

\begin{tabular}{|c|c|c|c|c|c|}
\hline & & Range & Mode & $\mathrm{MIC}_{50}$ & $\mathrm{MIC}_{90}$ \\
\hline \multirow[t]{3}{*}{ Fluoroquinolones } & Danofloxacin & 0.078 to $\geq 10$ & 0.156 & 0.156 & 0.312 \\
\hline & Enrofloxacin & 0.078 to $\geq 10$ & 0.156 & 0.156 & 0.312 \\
\hline & Marbofloxacin & 0.312 to $\geq 10$ & 0.625 & 0.625 & 0.625 \\
\hline \multirow[t]{2}{*}{ Aminoglycosides } & Gentamicin & 2 to 16 & 4 & 4 & 8 \\
\hline & Spectinomycin & 2 to $\geq 256$ & $\geq 256$ & $\geq 256$ & $\geq 256$ \\
\hline \multirow[t]{2}{*}{ Tetracyclines } & Oxytetracycline & 2 to $\geq 64$ & $\geq 64$ & $\geq 64$ & $\geq 64$ \\
\hline & Tetracycline & $\geq 0.25$ to 16 & 8 & 8 & 16 \\
\hline \multirow[t]{2}{*}{ Macrolides } & Tylosin & $\geq 0.5$ to $\geq 128$ & $\geq 128$ & $\geq 128$ & $\geq 128$ \\
\hline & Tilmicosin & $\geq 0.5$ to $\geq 128$ & $\geq 128$ & $\geq 128$ & $\geq 128$ \\
\hline Phenicol & Florfenicol & 4 to 8 & 4 & 4 & 8 \\
\hline Lincosamide & Lincomycin & 0.5 to $\geq 64$ & $\geq 64$ & $\geq 64$ & $\geq 64$ \\
\hline
\end{tabular}

All values are expressed as $\mu \mathrm{g} / \mathrm{ml}$. 
than isolates from Belgium and Israel $\left(\mathrm{MIC}_{90} 6 \mu \mathrm{g} / \mathrm{ml}\right.$, $32 \mu \mathrm{g} / \mathrm{ml})[13,19]$. Spectinomycin, another member of the aminoglycosides, was used traditionally as an active compound against $M$. bovis and it is still considered effective in Japan $[6,12,14]$. However, high MIC values of spectinomycin $(\geq 256 \mu \mathrm{g} / \mathrm{ml})$ were observed in more than half of the studied Hungarian isolates, which is in agreement with recent reports from other countries [7,13,15-17,19], confirming a globally emerging resistance to spectinomycin.

Heterogenic profiles of $M$. bovis susceptibility to tetracyclines are reported from all over the world $[6,7,13,14,16,19]$. Only two Hungarian isolates showed low MIC value to oxytetracycline and tetracycline, demonstrating the high level of resistance to tetracyclines among the strains. In accordance with our results, increasing resistance to oxytetracycline was reported previously in Britain, Belgium, Japan and France $[7,14,16,19]$.

All but two of the Hungarian M. bovis strains showed high level of resistance to macrolides, with $\mathrm{MIC}_{90}$ values $(\geq 128 \mu \mathrm{g} / \mathrm{ml})$ consistent with previously published data, suggesting that macrolides are losing their efficacy on mycoplasmas $[6,7,13,14,16]$. For example an earlier clinical study demonstrated the effective use of tilmicosin [20] but another study [21] twelve years later already demonstrated the ineffectiveness of tilmicosin against $M$. bovis in vivo which also emphasizes the spread of antibiotic resistance due to the escalating use of antibiotics in veterinary practice. In the present study MICs of tilmicosin grouped around two distinct values, while the distribution of MICs of tylosin was gradually dispersed (Figure 2H-I). MIC values of tylosin were lower $(8-128 \leq \mu \mathrm{g} / \mathrm{ml})$ or similar to MICs of tilmicosin $(\geq 128 \mu \mathrm{g} / \mathrm{ml})$. Similar observations were reported in the case of $M$. bovis strains by Gerchman et al. [13] and in the case of $M$. gallisepticum isolates by Jordan and Horrocks [22]. The slower development of tylosin resistance is supposed to be the cause of the difference between the MIC values of these antibiotics [23], and our results provide further evidence for this phenomenon.

Outstandingly low MIC values of all tetracyclines and macrolides were observed in two Hungarian isolates originating from the same herd (MYC52-53) and in the case of the reference PG45 strain. These three strains were closely related and they also formed a separate genetic clade in the MLST analysis performed previously [10].

The Hungarian isolates showed high MIC values to florfenicol. The $\mathrm{MIC}_{90}$ values $(8 \mu \mathrm{g} / \mathrm{ml})$ were similar to values obtained earlier in the United Kingdom $(16 \mu \mathrm{g} / \mathrm{ml})$, USA $(4 \mu \mathrm{g} / \mathrm{ml})$ and France $(16 \mu \mathrm{g} / \mathrm{ml})[6,7,16]$.

$\mathrm{MIC}_{90}$ values of lincomycin $(\geq 64 \mu \mathrm{g} / \mathrm{ml})$ were higher than the ones $(1 \mu \mathrm{g} / \mathrm{ml}, 8 \mu \mathrm{g} / \mathrm{ml}, 64 \mu \mathrm{g} / \mathrm{ml})$ described elsewhere $[12,14,19]$; and more than half of the strains isolated from cattle in Hungary demonstrated high MIC values to this member of lincosamides.
The results of in vitro antibiotic susceptibility tests can only predict the expected in vivo efficacy of the antibiotics, thus they only indicate the potential usefulness of a certain antimicrobial agent in the therapy. Standard breakpoints (susceptible, intermedier, resistant categories) have not yet been defined for the interpretation of M. bovis susceptibility to antibiotics [24], but several authors derived breakpoints for mycoplasmas from breakpoints of other bovine pathogens, and in some cases values were adopted from other host species [6,13-17]. Taking into account all these criteria, fluoroquinolones seem to be the most active compounds in vivo against the $M$. bovis strains existing in Hungary. Although the in vitro antibiotic susceptibility tests are promising, the use of fluoroquinolones against $M$. bovis could be controversial in vivo. In the United Kingdom Nicholas and Ayling [3] reported on a study where the monthly fluoroquinolone treatment repeated over three months did not prevent the development of respiratory disease caused by $M$. bovis.

\section{Conclusions}

The present study determined the antibiotic susceptibility profiles of $35 \mathrm{M}$. bovis strains isolated from cattle in Hungary and it highlighted the importance of regular testing of antibiotic susceptibility in the region. Our results confirmed the increasing resistance to antibiotics commonly used for the treatment of mycoplasma infections, primarily to tetracyclines and macrolides. Based on the presented in vitro examinations, fluoroquinolones could be the most effective in the therapy of $M$. bovis infections in Hungary. However, the identification of three fluoroquinolon resistant isolates lends support for the EU recommendation that prudent antimicrobial use policies have to be strictly observed when members of this antibiotic group are applied [25]. In order to avoid the development of resistance fluoroquinolones should only be used based on the results of susceptibility testing and in cases of severe infections when treatment failed with other classes of antimicrobials.

\section{Abbreviations}

MIC: Minimal inhibitory concentration; MLST: Multi-locus sequence typing.

\section{Competing interests}

The authors declare that they have no competing interests.

\section{Authors' contributions}

KMS and ZK performed the microbroth dilution tests, analysed the data and wrote the manuscript. LF and VH performed the microbroth dilution tests. TM and KE analysed the data and wrote the manuscript. SJ, NS, IT and LM collected the samples and isolated the strains. MG designed the study, analysed the data and wrote the manuscript. All authors read and approved the final manuscript.

\section{Acknowledgements}

This work was supported by the Lendület program (LP2012-22) of the Hungarian Academy of Sciences. 


\section{Author details}

'Institute for Veterinary Medical Research, Centre for Agricultural Research, Hungarian Academy of Sciences, Hungária körút 21, Budapest 1143, Hungary. ${ }^{2}$ Veterinary Diagnostic Directorate, National Food Chain Safety Office, Tábornok utca 2, Budapest 1143, Hungary. ${ }^{3}$ Faculty of Veterinary Science, Szent István University, Hungária körút 23-25, Budapest 1143, Hungary.

Received: 17 June 2014 Accepted: 14 October 2014

Published online: 25 October 2014

\section{References}

1. Hale HH, Helmboldt CF, Plastridge WN, Stula EF: Bovine mastitis caused by Mycoplasma species. Cornell Vet 1962, 52:582-591.

2. Maunsell FP, Woolums AR, Francoz D, Rosenbusch RF, Step DL, Wilson DJ, Janzen ED: Mycoplasma bovis infections in cattle. J Vet Intern Med 2011, 25:772-783.

3. Nicholas RAJ, Ayling RD: Mycoplasma bovis: disease, diagnosis, and control. Res Vet Sci 2003, 74:105-112.

4. Tenk M, Stipkovits L, Hufnagel L: Examination of the role of Mycoplasma bovis in bovine pneumonia and a mathematical model for its evaluation. Acta Vet Hung 2004, 52:445-456.

5. Nicholas RAJ, Wood E, Baker S, Ayling RD: Mycoplasmas isolated from ruminants in Britain 1995-2000. In Mycoplasmas of Ruminants: Pathogenicity, Diagnostics, Epidemiology and Molecular Genetics, Volume 5. Edited by Poveda JB, Fernandez A, Frey J, Johansson KE. Brussels: European Commission; 2001:116-120.

6. Rosenbusch RF, Kinyon JM, Apley M, Funk ND, Smith SC, Hoffman LJ: In vitro antimicrobial inhibition profiles of Mycoplasma bovis isolates recovered from various regions of the United States from 2002 to 2003. J Vet Diagn Invest 2005, 17:436-441.

7. Ayling RD, Baker SE, Peek ML, Simon AJ, Nicholas RA: Comparison of in vitro activity of danofloxacin, florfenicol, oxytetracycline, spectinomycin and tilmicosin against recent field isolates of Mycoplasma bovis. Vet Rec 2000, 146:745-747.

8. Subramaniam S, Bergonier D, Poumarat F, Capaul S, Schlatter Y, Nicolet J, Frey J: Species identification of Mycoplasma bovis and Mycoplasma agalactiae based on the uvrC genes by PCR. Mol Cell Probes 1998, 12:161-169

9. Lauerman LH, Chilina AR, Closser JA, Johansen D: Avian mycoplasma identification using polymerase chain reaction amplicon and restriction fragment length polymorphism analysis. Avian Dis 1995, 39:804-811.

10. Sulyok KM, Kreizinger Z, Fekete L, Jánosi S, Schweitzer N, Turcsányi I, Makrai L, Erdélyi K, Gyuranecz M: Phylogeny of Mycoplasma bovis isolates from Hungary based on multi locus sequence typing and multiple-locus variable-number tandem repeat analysis. BMC Vet Res 2014, 10:108.

11. Hannan PC: Guidelines and recommendations for antimicrobial minimum inhibitory concentration (MIC) testing against veterinary mycoplasma species. Vet Res 2000, 31:373-395.

12. ter Laak EA, Noordergraaf JH, Verschure MH: Susceptibilities of Mycoplasma bovis, Mycoplasma dispar, and Ureaplasma diversum strains to antimicrobial agents in vitro. Antimicrob Agents Chemother 1993, 37:317-321.

13. Gerchman I, Levisohn S, Mikula I, Lysnyansky I: In vitro antimicrobial susceptibility of Mycoplasma bovis isolated in Israel from local and imported cattle. Vet Microbio/ 2009, 137:268-275.

14. Uemura R, Sueyoshi M, Nagatomo H: Antimicrobial susceptibilities of four species of Mycoplasma isolated in 2008 and 2009 from cattle in Japan. J Vet Med Sci 2010, 72:1661-1663.

15. Francoz D, Fortin M, Fecteau G, Messier S: Determination of Mycoplasma bovis susceptibilities against six antimicrobial agents using the E test method. Vet Microbiol 2005, 105:57-64.

16. Gautier-Bouchardon AV, Ferré S, Le Grand D, Paoli A, Gay E, Poumarat F: Overall decrease in the susceptibility of Mycoplasma bovis to antimicrobials over the past 30 years in France. PLoS One 2014, 9:e87672

17. Soehnlen MK, Kunze ME, Karunathilake KE, Henwood BM, Kariyawasam S, Wolfgang DR, Jayaro BM: In vitro antimicrobial inhibition of Mycoplasma bovis isolates submitted to the Pennsylvania Animal Diagnostic Laboratory using flow cytometry and a broth microdilution method. J Vet Diagn Invest 2011, 23:547-551.
18. Kroemer S, Galland D, Guérin-Faublée V, Giboin H, Woehrlé-Fontaine F: Survey of marbofloxacin susceptibility of bacteria isolated from cattle with respiratory disease and mastitis in Europe. Vet Rec 2012, 170:53-53.

19. Gourlay RN, Thomas LH, Wyld SG, Smith CJ: Effect of a new macrolide antibiotic (tilmicosin) on pneumonia experimentally induced in calves by Mycoplasma bovis and Pasteurella haemolytica. Res Vet Sci 1989, 47:84-89.

20. Haines DM, Martin KM, Clark EG, Jim GK, Janzen ED: The immunohistochemical detection of Mycoplasma bovis and bovine viral diarrhea virus in tissues of feedlot cattle with chronic, unresponsive respiratory disease and/or arthritis. Can Vet J 2001, 42:857.

21. Thomas A, Nicolas C, Dizier I, Mainil J, Linden A: Antibiotic susceptibilities of recent isolates of Mycoplasma bovis in Belgium. Vet Rec 2003, 153:428-431.

22. Jordan FTW, Horrocks BK: The minimum inhibitory concentration of tilmicosin and tylosin for Mycoplasma gallisepticum and Mycoplasma synoviae and a comparison of their efficacy in the control of Mycoplasma gallisepticum infection in broiler chicks. Avian Dis 1996, 40:326-334.

23. Wu CM, Wu H, Ning Y, Wang J, Du X, Shen J: Induction of macrolide resistance in Mycoplasma gallisepticum in vitro and its resistance-related mutations within domain V of $23 \mathrm{~S}$ rRNA. FEMS Microbiol Lett 2005, 247:199-205.

24. National Committee for Clinical Laboratory Standards (NCCLS): Performance standards for antimicrobial disk and dilution susceptibility tests for bacteria isolated from animals. Wayne, PA: Approved Standard (Fourth Edition) and second informational supplement. NCCLS document VET01-A4 and VET01-S2. NCCLS 2013; 2013.

25. European Medicines Agency, EMA/186029/2010. http://www.ema.europa.eu/ ema/index.jsp?curl=pages/medicines/veterinary/referrals/Quinolones containing_medicinal_products/vet_referral_000039.jsp\&mid= WC0b01ac05800986a1.

\section{doi:10.1186/s12917-014-0256-x}

Cite this article as: Sulyok et al:: Antibiotic susceptibility profiles of Mycoplasma bovis strains isolated from cattle in Hungary, Central Europe. BMC Veterinary Research 2014 10:256.

\section{Submit your next manuscript to BioMed Central and take full advantage of:}

- Convenient online submission

- Thorough peer review

- No space constraints or color figure charges

- Immediate publication on acceptance

- Inclusion in PubMed, CAS, Scopus and Google Scholar

- Research which is freely available for redistribution 